БУТЬКО Т. В., д. т. н., професор, завідувач кафедри управління експлуатаційною роботою, ХАРЛАНОВА С. В., аспірант, КІПРЕНКО А. В., магістрант, ШАХРАЮК В. А., магістрант

(Український державний університет залізничного транспорту)

\title{
Підходи до удосконалення контейнерних інтермодальних перевезень в умовах впровадження приватної локомотивної тяги
}

Перспективність збільшення контейнерних перевезень є одним з найважливіших напрямків розвитку зовнішньоекономічних відносин України з країнами-партнерами. Для забезпечення таких великих обсягів перевезень контейнерів залізнична галузь має реформуватись дуже швидко та оперативно реагувати на запити вантажовласників. Для визначення наявної ситуацї у сфері вантажних контейнерних перевезень виконано аналіз статистичних даних за попередні періоди.

Експериментальні дослідження в межах України довели, щуо найбільші простої контейнерів спостерігаються на «першій милі» $i$ на «останній милі». В статті запропоновано підхід, щзо дає змогу порівняти питомі експлуатаційні витрати на один контейнер в умовах перевезень «за готовністю», який на сьогодні діє на АТ «Укрзалізниця», $i$ «за часом» при наданні «жорсткої нитки» графіка руху поїздів.

Проведений порівняльний аналіз питомих експлуатаційних витрат на запропонованому маршруті доводить доиільність використання приватної локомотивної тяги, щзо є особливо актуальним в умовах старіння $i$ дефіциту тягового рухомого складу та розвитку економічних зв'язків між країнами.

Ключові слова: контейнери, інтермодальні перевезення, залізниця, порт, приватна локомотивна тяга.

\begin{tabular}{l}
\hline Вступ \\
\hline у світі 3 кожним роком спостерігається \\
збільшення обсягів інтермодальних контейнерних \\
перевезень. Залізниця є безпосереднім учасником \\
інтермодальних перевезень на ринку загальних \\
європейських залізничних вантажоперевезень, який \\
динамічно показує щорічний приріст в обсягах +50 \%. \\
Позитивна динаміка контейнерних перевезень в \\
Україні демонструє зростання ринку в середньому на \\
13 - 15 \% щороку. За перші чотири місяці 2020 року \\
залізницею в складі контейнерних поїздів перевезено \\
90 тис. ТЕU, що більш ніж у два рази перевищує \\
обсяги перевезень за аналогічний період 2019 року.
\end{tabular}

Однією 3 причин гальмування розвитку інтермодальних залізничних контейнерних перевезень в Україні, що може спричинити зменшення обсягів вантажних перевезень та підвищення експлуатаційних витрат, є дефіцит локомотивного парку.

Для забезпечення конкурентоспроможності залізничного транспорту на ринку контейнерних перевезень доцільним $\epsilon$ впровадження приватної локомотивної тяги в умовах надання «жорсткої нитки» графіка руху поїздів.

Для реалізації такої технології необхідно формалізувати процес перевезення контейнерів у вигляді математичної моделі, що у свою чергу буде сприяти подальшій автоматизації при управлінні.

\section{Аналіз попередніх досліджень}

Вагомий внесок у дослідження i формування контейнерних перевезень зробили такі науковці: Бутько Т. В., Ломотько Д. В., Прохоров В. М., Пархоменко Л. О., Колісник А. В., Алексейчук Н. М. $[1,2,3]$. Щодо удосконалення перевезень контейнерів в інтермодальних перевезеннях сформовано адекватні математичні моделі, але не враховано можливості впровадження приватної локомотивної тяги.

У публікації [3] обгрунтовано технологічні та організаційні заходи щодо удосконалення технологічного забезпечення контейнеропотоків; розроблено математичні моделі процесів технологічного забезпечення контейнерних перевезень 3 використанням резервів провізних спроможностей залізничного транспорту, але також не враховано можливості впровадження приватної тяги з наданням «жорсткої нитки» графіка руху поїздів (ГРП).

\section{Мета дослідження}

Метою роботи $\epsilon$ проведення статистичних досліджень щодо обсягів та динаміки контейнерних перевезень, формалізація процесу накопичення контейнерів на терміналі та обгрунтування доцільності використання приватної локомотивної тяги при перевезенні контейнерних поїздів до морського порту.

(C) Т. В. Бутько, С. В. Харланова, А. В. Кіпренко, В. А. Шахраюк, 2021 


\section{Виклад основного матеріалу}

Сучасна світова економіка розвивається колосальними темпами, економічні відносини стають більш комплексними, багатошаровими i багатоступінчатими. У забезпеченні сталого розвитку цих відносин важливу роль відіграє транспорт. Залізничний транспорт $є$ одним 3 найпопулярніших видів транспорту для вантажних перевезень.

На підставі проведеного аналізу обсягів вантажних перевезень можна дійти висновку, що залізничний транспорт втрачає частку ринку перевезень через автомобільний транспорт. Автомобільний транспорт 3 кожним роком збільшує свою частку перевезень у загальному обсязі вантажних перевезень. Це обумовлено тим, що автомобільний транспорт більш зручний для невеликих відправок вантажів і більш незалежний від різних обставин при організації логістики. 3 кожним роком в Україні набувають популярності контейнерні та контрейлерні перевезення. Це пов’язано з тим, що велика кількість товарів імпортується 3 країн Європи, Китаю та Америки за допомогою різних видів транспорту в універсальних контейнерах. За статистикою, найбільший обсяг контейнерних перевезень припадає на порти країн - учасників інтермодальних перевезень. Завдяки своєму географічному розташуванню Україна $\epsilon$ сполучною ланкою між країнами Західної Європи та Китаю, що активно розвиває свої торгові шляхи. Підтвердженням цієї тенденції є діаграми розподілів контейнеропотоків, що наведено на рис. 1 i рис. 2 відповідно.

На рис. 1 відображено статистичні дані порівняння обсягів контейнерних перевезень та знімних кузовів трейлерів серед країн ЄС. Найбільша кількість перевезених контейнерів припадає на такі країни, як Греція, Італія, Ірландія, Норвегія, Швейцарія, Іспанія, Португалія, Німеччина, Англія та ін. Також на діаграмі зображено контрейлерні перевезення із супроводом i без нього. Лідером серед усіх країн за кількістю контрейлерних перевезень без супроводу є Норвегія, а iз супроводом - Швейцарія [5].

На рис. 2 зображено найбільш навантажені напрямки перевезень контейнерів по маршрутах, що проходять територією України, та інші маршрути, по яких контейнерні поїзди проходять транзитом [6].

Наведені діаграми доводять, що збільшення обсягів та перспективи контейнерних інтермодальних перевезень мають домінуючу тенденцію, що підтверджує цей позитивний тренд як у світі, так зокрема й в Україні.

\section{Rail transport of intermodal transport units, 2017}

(\% share on total rail freight transport in tonne-kilometres)

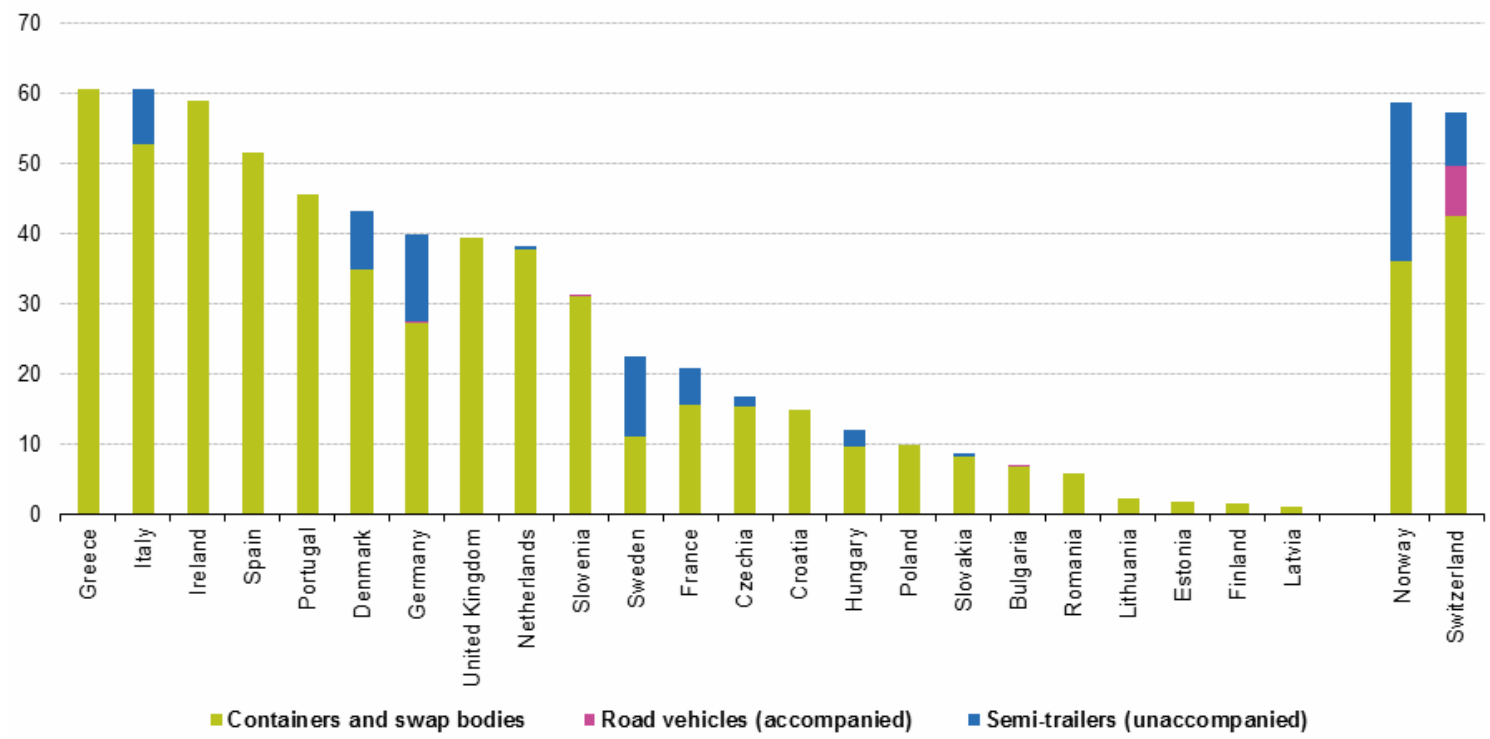

Рис. 1. Розподіл обсягів перевезень контейнерів залізничним транспортом у складі інтермодальних перевезень по країнах СС 


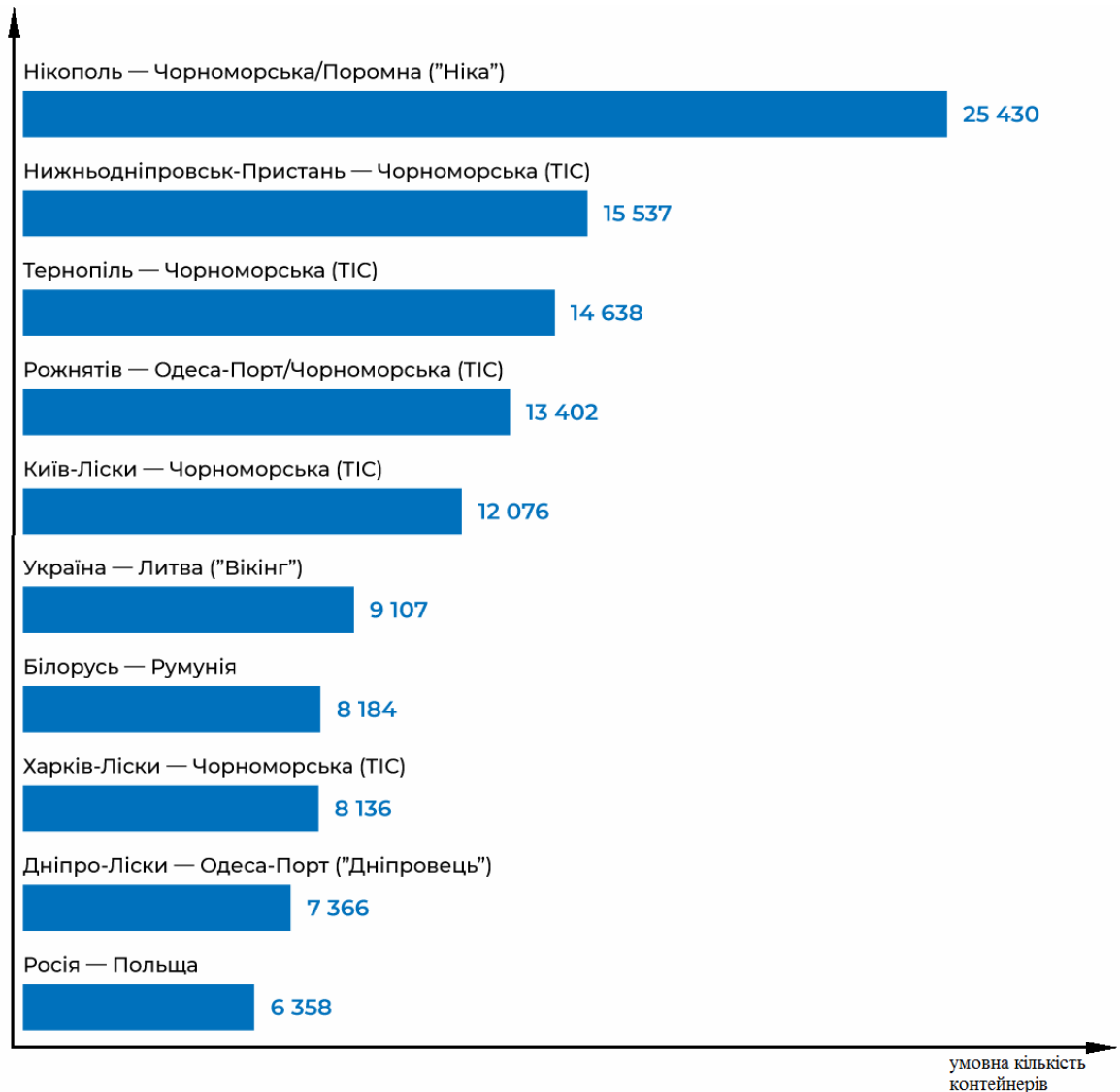

Рис. 2. Діаграма розподілу кількості контейнерів за напрямками, що проходять транзитом та перевозяться територією України

Водночас експериментальні дослідження на контейнерних терміналах України довели, що значний простій контейнерів спостерігається як на терміналі відправлення («перша миля»), так і безпосередньо на припортовій станції («остання миля»).

При цьому час надходження на контейнерний термінал має стохастичний характер [4]. На підставі досліджень отримано, що простій контейнерів як на терміналі відправлення, так і на терміналі призначення підпорядкований нормальному закону розподілу 3 такими параметрами:

1. Математичне сподівання часу простоювання контейнерів на терміналі відправлення $\bar{t}_{n}=181,8$ год, а на терміналі призначення $\bar{t}_{\kappa}=171,2$ год.

2. Середнє квадратичне відхилення на станції відправлення $\sigma_{n}=59,2$ год, а на станції призначення $\sigma_{\kappa}=66,1$ год.

Аналіз цих показників доводить, що величина контейнеро-годин простоювання як на «першій», так i на «останній милі» $є$ достатньо великою. Саме це $\epsilon$ основною причиною удосконалення технології перевезення контейнеропотоків.
На основі аналізу існуючої технології було сформовано принципову схему перевезень контейнерів (рис. 3).

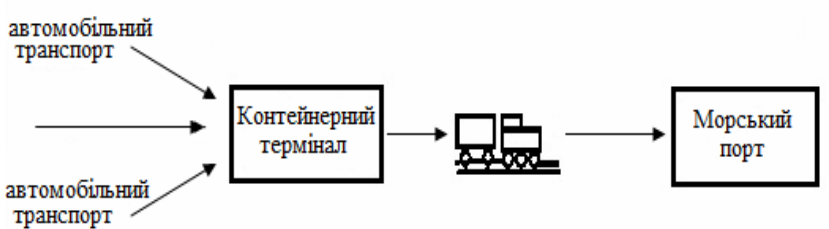

Рис. 3. Принципова схема перевезень контейнерів

На сьогодні існують два підходи до реалізації процесу перевезень - «за готовністю», що використовується нині на АТ «Укрзалізниця», і «за часом» при перевезенні приватним локомотивом «за жорсткою ниткою» графіка руху поїздів (ГРП).

Для реалізації процесу перевезень контейнерів «за готовністю» состава $3 \mathrm{~N}$ платформами доцільно використовувати вираз: 
$N=\int_{t_{0}}^{\tau} \lambda_{K}(t) d t$

де $\lambda_{K}(t)$ - інтенсивність контейнеропотоку, що надходить на термінал накопичення;

$t_{0}$ - момент часу початку накопичення;

$\tau$ - момент часу закінчення накопичення $N$ контейнерів.

Тоді сумарні експлуатаційні витрати $C_{2}(2)$, що припадають на один контейнер при перевезенні контейнерним поїздом (без переробки на сортувальних станціях) «за готовністю», складатимуть:

$C_{\Gamma}=\left(\frac{\mathrm{N} \cdot\left(\tau-t_{o}\right)}{2}+\frac{t_{o u}}{\mathrm{~N}}\right) C_{K}+\bar{t}_{n e p}\left(C_{\Pi \Gamma}+C_{K}\right)$,

де $t_{o ч}$ - час очікування на подавання локомотива, год;

$N$ - кількість контейнерів у поїзді;

$C_{K}-$ вартість контейнеро-годин, грн/год;

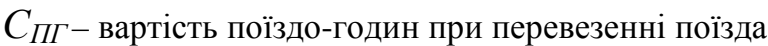
«за готовністю» локомотивом залізниці, грн/год;

$\bar{t}_{n e p}$ - час на перевезення контейнерів поїздом до пункту призначення, год.

Враховуючи, що випадкова величина часу знаходження контейнера $t$ на терміналі («перша миля») підпорядкована нормальному закону розподілу 3 параметрами $\bar{t}_{\Pi}$ і $\sigma_{n}$, які наведено вище, середній час перебування контейнера до моменту $t_{1}$, надання «жорсткої нитки» ГРП доцільно розрахувати за формулою:

$\overline{\mathrm{t}}_{\mathrm{B}}=\frac{1}{\sigma \sqrt{2 \pi}} \int_{\mathrm{t}_{0}}^{\mathrm{t}_{1}} \mathrm{t} \cdot \exp \left(-\frac{\left(t-\bar{t}_{\Pi}\right)^{2}}{2 \sigma^{2}}\right) d t$.

Тоді сумарні питомі експлуатаційні витрати, що припадають на один контейнер при перевезенні до терміналу порту або західного кордону приватним локомотивом «за жорсткою ниткою», складатимуть:

$C_{\text {ЖH }}=\overline{\mathrm{t}}_{\Pi} \cdot C_{K}+\overline{\mathrm{t}}_{\Pi е р} \cdot\left(C_{\Pi \Gamma}^{A}+C_{K}\right)$,

де $C_{K}-$ вартість контейнеро-годин, грн/год;

$C_{П Г}^{A}$ - вартість поїздо-годин 3 урахуванням амортизаційних відрахувань на придбання або оренду приватного локомотива, грн/год;

$\overline{\mathrm{t}}_{\text {пер }}$ - час на перевезення контейнерів поїздом до пункту призначення, год.
При цьому для обох випадків кількість контейнерів $\quad N<N_{\max }$, де $N_{\max }$ - відповідає максимальній масі состава за тяговими розрахунками; також довжина поїзда має бути менше або дорівнювати довжині приймально-відправних колій на терміналі $N \cdot l_{y_{м}}<l_{\Pi в K}$, де $l_{y_{M}}$ - умовна довжина вагона, $l_{П в К}$ - довжина приймально-відправних колій на терміналі.

Для наочного відображення доцільності впровадження приватної локомотивної тяги пропонується як приклад розглянути маршрут прямування контейнерного поїзда від Х-Л до ОдесаПорт, який $є$ одним 3 ключових у забезпеченні зовнішньоекономічного обігу товарів (рис. 4).

Загальна довжина маршруту складає 761 км. Запропонований маршрут повністю електрифікований, що дає змогу використовувати електричну тягу для перевезення, але на деяких дільницях живлення здійснюється різним видом струму. Весь Харківський залізничний вузол живиться постійним електричним струмом, тоді як більшість електрифікованих дільниць запропонованого маршруту живиться змінним струмом. Це висуває певні вимоги до серії електровоза для перевезення контейнерів, оскільки він має бути оснащений тяговими генераторами двох видів - для роботи на постійному та змінному електричному струмі. Частина маршруту від станції Х-Л до станції Огульці має живлення постійним струмом. Перехід від постійного на змінний струм здійснюється на станції Огульці (Південної залізниці). Інша частина маршруту до станції Одеса-Порт оснащена тяговими підстанціями змінного струму.

На основі аналізу існуючих типів електровозів було обрано електровоз фірми Siemens cepiï Vectron MS (мультисистемний) (рис. 5) для колії 1524 мм [7]. 


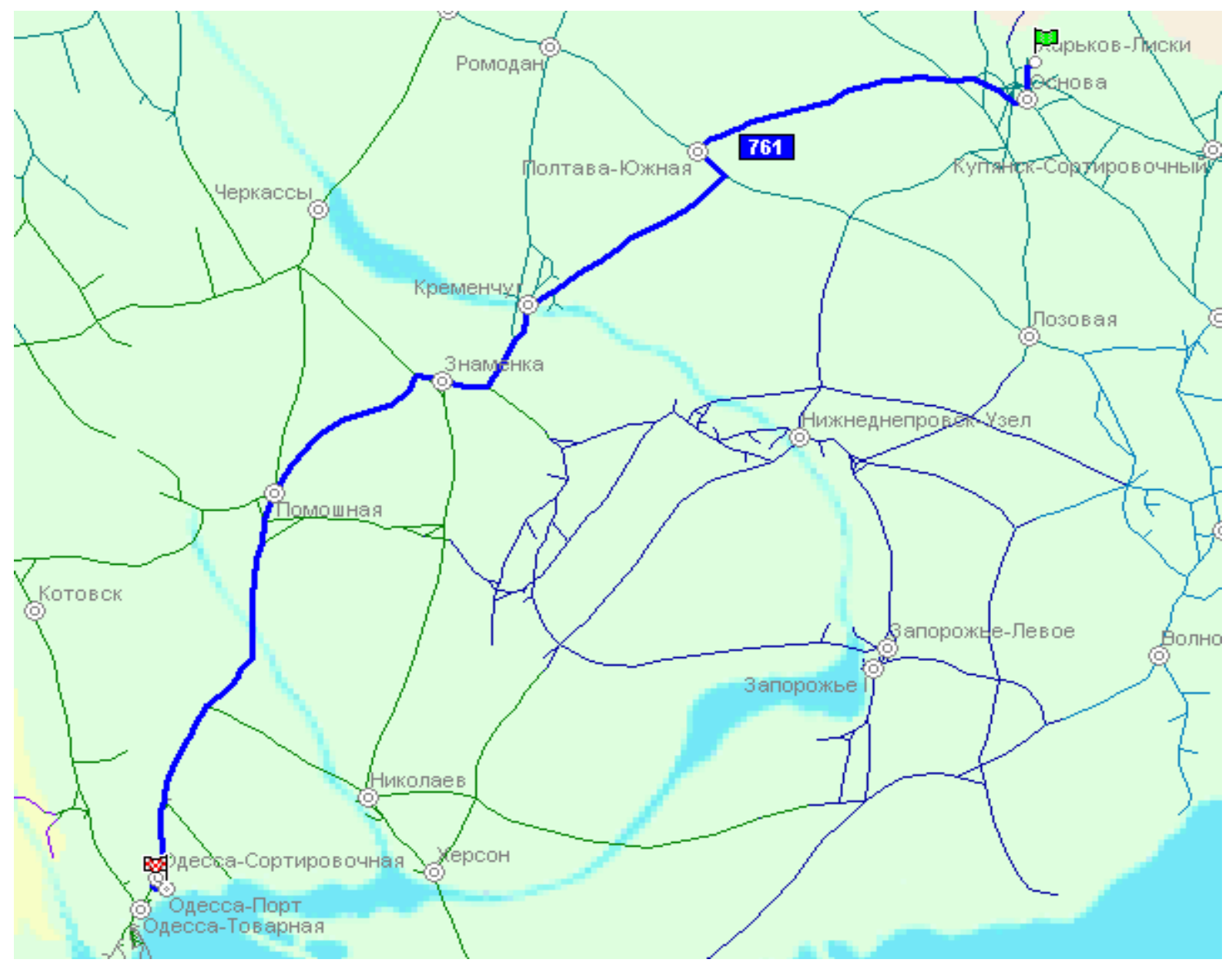

Рис. 4. Схема маршруту контейнерного поїзда від станції Х-Л до станції Одеса-Порт

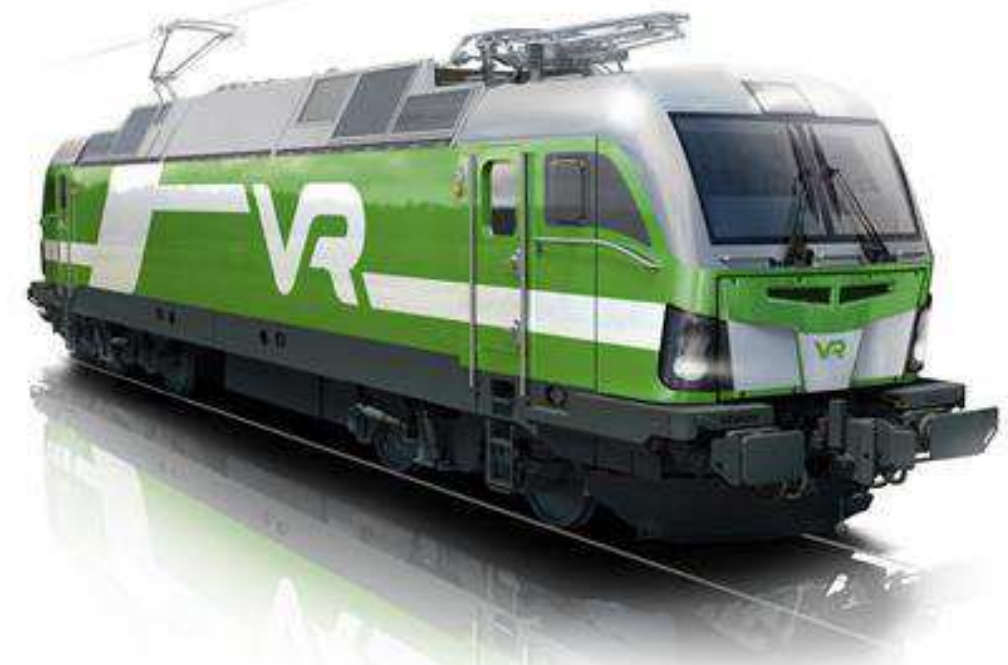

Рис. 5. Електровоз Siemens Vectron MS для залізниці Фінляндії (1524 мм) 
Цей електровоз був розроблений безпосередньо для Фінляндії, має деякі конструктивні особливості, які враховують кліматичні умови країни, та адаптований для використання на дільницях 3 постійним та змінним струмом. Він також оснащений додатковими дизельними генераторами для можливості здійснення маневрових пересувань на дільницях без електрифікації. Максимальна конструкційна швидкість, яку може розвивати електровоз, - 200 км/год. Він здатен перевезти состав масою 2000 тонн, що $є$ прийнятною величиною для перевезення контейнерних поїздів.

Виходячи 3 того, що конструкційна швидкість дорівнює 200 км/год, приймаємо середньо-ходову швидкість по маршруту 100 км/год, для «жорсткої нитки» графіка. За такої швидкості состав проїде визначену відстань по маршруту, приблизно, за 7 годин 37 хвилин, якщо не враховувати форс-мажорів та суттєвих обмежень щодо швидкості на коліях залізниці. Отже, можна зробити висновок, що на шляху прямування зміна локомотивної бригади не потрібна. Цей аспект дає змогу економити час прямування по маршруту i їхати від пункту відправлення до пункту призначення без зупинок, по «жорсткій нитці» графіка.

Для реалізації такої технології перевезень за «жорсткою ниткою» доцільно організувати в межах терміналів накопичення локомотивні депо для проведення ТО-2 та екіпірування. При використанні технології перевезення «за готовністю» середній час прямування контейнерного поїзда по аналогічному маршруту складає близько 17 годин.

На підставі порівняльного аналізу використання двох підходів при перевезенні контейнерних поїздів доведено доцільність запровадження приватної локомотивної тяги та перевезення контейнерних поїздів за «жорсткою ниткою».

Порівнюючи залежності питомих експлуатаційних витрат як функцій від кількості контейнерів $\mathrm{N}$ для двох варіантів відправлення поїзда - «за жорсткою ниткою» приватним локомотивом i традиційним варіантом «за готовністю», отримано такі залежності (рис. 6 ).

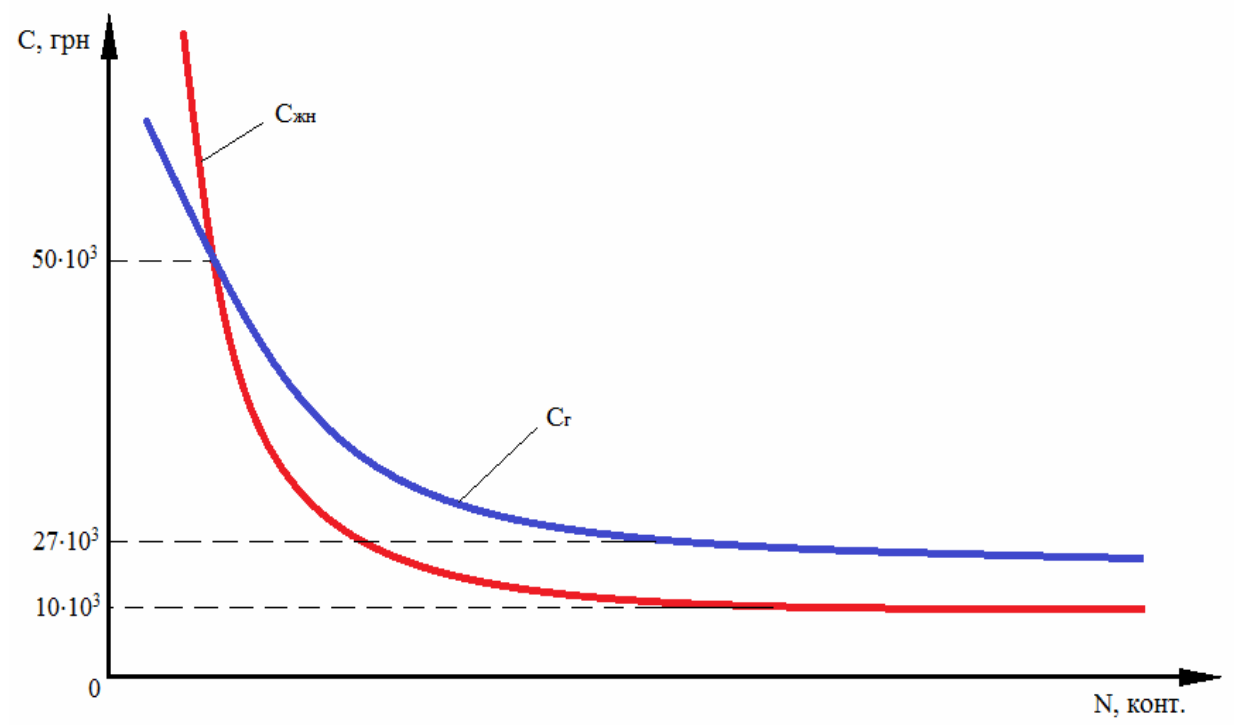

Рис. 6. Залежність питомих експлуатаційних витрат, що припадають на контейнер, для двох варіантів перевезень

Запропонований підхід доцільно застосовувати тільки для контейнерних поїздів, які прямують до станції призначення без переробки на сортувальних станціях. Якщо ще додати середній час простою на сортувальних станціях 3 місць відправлення та призначення, то більш вигідним стає підхід 3 використанням приватного локомотива «за жорсткою ниткою» графіка. Але це порівняння також не враховує операцій по прибуттю у порт, оскільки термін їх виконання однаковий.

\section{Висновки}

У статті подано порівняльний аналіз перевезення контейнерів до пункту призначення при застосуванні двох підходів: «за готовністю» i «за жорсткою ниткою» графіка руху поїздів приватним локомотивом, який доводить доцільність використання приватної локомотивної тяги для здійснення перевезень контейнерних поїздів, оскільки на сьогоднішній день час прямування контейнерного поїзда по запропонованому маршруту складає близько 17 годин, 
а після застосування підходу прямування «за жорсткою ниткою» приватним локомотивом час доставки контейнерів складатиме 7 годин 35 хвилин. На основі аналізу доведено, що як приватний локомотив доцільно обрати локомотив фірми Siemens Vectron MS, який зможе забезпечити перевезення контейнеропотоків по електрифікованих залізничних лініях в умовах України.

\section{Список використаних джерел}

1. Butko T., Prokhorov V., Kolisnyk A., Parkhomenko L. Devising an automated technology to organize the railroad transportation of containers for intermodal deliveries based on the theory of point Eastern-European journal of enterprise technologies. 2020. Vol. 1, № 3 (103). P. 6-12. DOI: 10.15587/1729- 4061.2019.156098 (видання індексується в базі Scopus).

2. Бутько Т. В., Колісник А. В., Пархоменко Л. О. Удосконалення організації взаємодії залізничних вузлів та портів при контейнерних перевезеннях. Інтелектуальні транспортні технологї: тези доповідей 1-ї міжнародної науково-технічної конференції (Трускавець - Харків, 24 - 30 січня 2020 р.) Харків: УкрДУЗТ, 2020. С. 13.

3. Алексійчук Н. М. Удосконалення технологічного забезпечення контейнерних перевезень 3 використанням резервів провізних спроможностей залізничного транспорту: автореф. дис. ... канд. техн. наук: 05.22.01. Київ. 2013. 24 с.

4. Колісник А. В. Формування автоматизованої технології транспортування контейнерів залізницею на основі теорії випадкових потоків: автореф. дис. ... канд. техн. наук: 01.10.20. Харків. 2020. 195 c.

5. Freight transported in containers - statistics on unitization. URL:

https://ec.europa.eu/eurostat/statisticsexplained/index.php/Freight_transported_in_container s_-_statistics_on_unitisation (дата звернення 25.01.2021)

6. Названы топ-10 самых загруженных контейнерных поездов в Украине в 2019 году (инфографика). URL: https://cfts.org.ua/news/2020/02/26/nazvany_ top_10_samykh_zagruzhennykh_konteynernykh_poez dov_v_ukraine_v_2019_godu_ infografika_57516 (дата звернення 20.01.2021).

7. Vectron (locomotive): From Wikipedia, the free encyclopedia.

URL: https://en.wikipedia.org/wiki/Vectron_(locomotive) (дата звернення: 01.02.2021).
Бутько Т. В., Харланова С. В., Кипренко А. В., Шахраюк В. А. Подходы к усовершенствованию контейнерных интермодальных перевозок В условиях внедрения частной локомотивной тяги.

Аннотация. Перспективность увеличения
контейнерных перевозок является одним из важнейших направлений развития внешнеэкономических отношений Украины со странами-партнерами. Для обеспечения таких больших объемов перевозок контейнеров железнодорожная отрасль должна реформироваться и оперативно реагировать на запросы грузовладельцев. Для определения сложившейся ситуации в сфере грузовых контейнерных перевозок был проведен анализ статистических данных за предыдущие периоды.

Экспериментальные исследования в пределах Украины доказали, что самые большие простои контейнеров наблюдаются на «первой миле» и на «последней миле». В статье предложен подход, позволяющий сравнить удельные эксплуатационные затраты на один контейнер в условиях перевозок «по готовности», который в настоящее время действует в АТ «Укрзалізниця», и «по времени» при предоставлении «жесткой нити» графика движения поездов.

Проведенный сравнительный анализ удельных эксплуатационных расходов на предложенном маршруте доказывает целесообразность использования частной локомотивной тяги, что особенно актуально в условиях старения, дефицита тягового подвижного состава и развития экономических связей между странами.

Ключевые слова: контейнеры, интермодальные перевозки, железная дорога, порт, частная локомотивная тяга.

Butko T. V., Kharlanova S. V., Kiprenko A. B., Shakhrayk B. A. Approaches to improvement of container intermodal transportation in the conditions of introduction of private locomotive traction.

Abstract. Prospects for increasing container traffic are one of the most important directions in the development of Ukraine's foreign economic relations with partner countries. To ensure such a large volume of container traffic, the railway industry must be reformed very quickly and respond quickly to the requests of cargo owners. To determine the current situation in the field of container shipping, an analysis of statistical data for previous periods was made.

The paper compares the volume of containers and detachable bodies with and without escort in the European Union and analyzes the routes of container trains by the number of transported conventional containers that pass 
through Ukraine in transit and follow directly within the country.

Experimental studies within Ukraine have shown that the largest downtime of containers is observed at the «first mil» and the «last mile». The article proposes an approach that allows to compare the specific operating costs per container, in terms of transportation «on standby», which currently operates at JSC «Ukrzaliznytsia» and «on time» when providing a «firm train path» of schedule.

To clearly reflect the feasibility of the proposed method, the existing routes of container transportation were analyzed, and the direction H-L - Odessa-Port was chosen, as this route is the longest, which passes through the territory of Ukraine. After analyzing all route indicators (length, electrification, travel time, etc.), the type and series of locomotives were determined, namely the proposed Siemens Vectron MS (multi-system) dualpower locomotive, because part of the route is electrified by DC and part by AC. Given the technical characteristics of the Vectron MS locomotive, namely the design speed of $200 \mathrm{~km} / \mathrm{h}$ and the traction force that allows the movement of trains weighing up to 2000 tons, it was proved that a container train can overcome this route in 7,5 hours. This affects the operating costs when using private locomotive traction, and provides the opportunity to carry out transportation by one locomotive crew.

The comparative analysis of specific operating costs on the proposed route proves the feasibility of using private locomotive traction, which is especially relevant in the context of aging and shortage of traction rolling stock, and economic ties between countries.

Key words: containers, intermodal transport, railway, port, private locomotive traction.

Надійшла 08.02.2021 p.

Butko Tetiana, Dr. Sc., professor, chief of department of Management of operational work, Ukrainian State University of Railway Transport. E-mail: butko@kart.edu.ua ID ORCID: https://orcid.org/00000003-1082-599X

Kharlanova Svitlana, post graduate, department of Management of operational work, Ukrainian State University of Railway Transport. E-mail: kharlanova.svetlana18@gmail.com ID ORCID: https://orcid.org/0000-0001-5489-9400 .

Kiprenko Alina, undergraduate, Ukrainian State University of Railway Transport, Kharkiv, Ukraine. E-mail: power.lamia@gmail.com

Shakhraiuk Violetta, undergraduate, Ukrainian State University of Railway Transport, Kharkiv, Ukraine. E-mail: letta.shahrayuk@gmail.com
Бутько Тетяна Василівна, д. завідувач кафедри, кафедра управління експлуатаційною роботою, Украӥнський державний університет залізничного транспорту. E-mail: butko@kart.edu.ua ID ORCID: https://orcid.org/00000003-1082-599X

Харланова Світлана Володимирівна, аспірант, кафедра управління експлуатачійною роботою, Украӥнський державний університет залізничного mpaнcnopmy. E-mail: kharlanova.svetlana18@gmail.com ID ORCID: https://orcid.org/0000-0001-5489-9400 .

Кіпренко Аліна Валентинівна, магістрант, Украӥнський державний університет залізничного mpaнсnорту. E-mail : power.lamia@gmail.com

Шахраюк Віолетта Андріївна, магістрант, Український державний університет залізничного mpaнcnopmy. E-mail: letta.shahrayuk@gmail.com 